\title{
EVALUATION OF FOUR NEW BARLEY CULTIVARS PRODUCTIVITY INTERCROPPED WITH BERSEEM CLOVER AT DIFFERENT SEEDING RATES IN NEW LANDS IN EGYPT
}

(Received:3.2.2015)

\author{
By \\ M. Z. Shendy \\ Barley Research Department, Field Crops Research Institute, \\ Agricultural Research Center, Giza, Egypt
}

\begin{abstract}
A field experiment was conducted at the Experimental Farm of Ismailia Agricultural Research Center, during the two successive growing seasons of 2012/2013 and 2013/2014. The treatments were arranged in a spilt-split plot in a randomized complete block design with three replications. Results showed the cutting treatments (without and one cut) had a significant effect on the number of spikes $\mathrm{m}^{-2}, 1000-\mathrm{kernel}$ weight $(\mathrm{g})$, the number of kernels/spike, spike kernel weight $(\mathrm{g})$,straw yield $\left(\mathrm{t} \mathrm{fed}^{-1}\right)$ grain yield $\left(\mathrm{t} \mathrm{fed}^{-1}\right)$ and protein content (\%).Except spike kernels weight and straw yield, the cultivar Giza136 (hull-less barley) gave the highest grain yield, yield components and protein content $\%$. On the other hand, cultivars G134 and G 133 showed the highest value for spike kernels weight and straw yield, respectively under the both treatments ( without cutting and one cut). The best intercropping system was obtained from intercropping barley cultivar G136 (37.5 kg seeds/fed.) and berseem Helaly cultivar (6.25 kg seeds/fed.). Moreover, the maximums value for spike kernel weight and straw yield were obtained under intercropping system of 75\% of barley cultivars (G134 or G133) with berseem $25 \%$ of cultivar Helaly. The hull-less barley cultivars outyield the hulled barley cultivars under the both treatments (without cutting and one cut).
\end{abstract}

Keywords: barley, berseem clover, intercropping, seeding rate.

\section{INTRODUCTION}

Intercropping cereals with legumes for forage or food production is used in many parts of the world for soil conservation. Intercrops including legumes is known to enhance forage crude protein concentration compared with cereal sole cropping, and to use resources more efficiently (Anil et al., 1998; Papastylianou, 2004). Monocultures of legumes or cereals do not provide in some cases, satisfactory results for forage production (Osman and Nersoyan, 1986). In particular, forage quality of small grain between cereals proveds, high yields in terms of DM but they produce forage with low crude protein (Lawes and Jones, 1971). In intercrops, competition cereals provide structural support for legume growth, improve light interception, and facilitates mechanical harvest, while legumes generally increase the protein and mineral content of forage (Robinson, 1969). Crop species, seeding rates, and competition between mixture components may affect yield and quality of forage produced by intercrops (Caballero et al. 1995). The main use of barley in Egypt is animal feeding. Recently, a new interest was born by using barley grains as human food especially the hull-less cultivars. Barley growers grow barley in Egypt to produce the crop as dual purposes, i. e. for feed and food. The traditional, if the season comes rainy, the farmers leave the sheep and goats to graze the plants lightly as green forage at the beginning of tillering stage, and the plants will grow again to produce heads, in turn grain yield. If the season comes droughty (low precipitation), the farmers leave their animals to graze the barley plants sharply. Barley biomass (straw and grains) used as dry forage in the desert during summer. Intercropping, which is defined as the growing of two or more crop species simultaneously in the same filed during a growing season (Ofori and Stem 1987), is important for the development of sustainable food production system, particularly in cropping systems with 
limited external inputs. Adesogan et al. (2000), found that all mixtures of vetch and barley had significantly higher digestible dry matter. The effects of seeding rates on yield and yield components of this intercrop are also limited in the literature. Different cultivars of spring barley react differently to increasing sowing rate (Jedel, and Helm, 1995). A good malting quality of the cultivars is related to a low protein content of the grain, while the reverse is true of fodder quality.

The objective of this study was to evaluate yield and yield components of new four cultivars of barley when intercropped with berseem clover under different seeding rates in new lands of Egypt

\section{MATERIALS AND METHODS}

Two field experiments were conducted at Ismailia Experimental Station Farm, ARC, in 2012/2013 and 2013/2014 winter seasons without cutting. To evaluate yield and yield components of barley four early maturing, cultivars (Giza 133, Giza 134 (hulled barley) and Giza 136, Giza 135 (hull-less barley)) and Helaly (berseem clover) were planted under 4 seeding rates and two cutting treatments (without cutting and one cut after 45 days from planting. Soil physical and chemical analyses of the experimental site was conducted in 2012/2013 and 2013/2014 seasons (Table 1).

Barley and berseem clover were planted in alternative rows at the same row spacing. Plot size was $4.80 \mathrm{~m}^{2}$. Each plot contained 8 rows spaced $20 \mathrm{~cm}$ apart within $3.0 \mathrm{~m}$ wide $\mathrm{X} 2.0 \mathrm{~m}$ long. All plots received $30 \mathrm{P}_{2} \mathrm{O}_{5} \mathrm{~kg}$ fed $^{-1}$. Potassium Sulphate $\left(48 \% \mathrm{~K}_{2} \mathrm{O}\right)$ added at the rate of $50 \mathrm{~kg} / \mathrm{fad}^{-1}$ before sowing. Nitrogen fertilizer was added as Ammonium Nitrate $(33.5 \% \mathrm{~N})$ at the rate of $60 \mathrm{~kg} \mathrm{~N} \mathrm{fed}^{-1}$ The amount of nitrogen fertilizer was added as three equal doses, i.e., the first at sowing, the second at shooting, i. e., 35 days after planting and the third at booting, i.e. 70 days after planting. Cutting started when plants reached $50 \mathrm{~cm}$ tall and the stubble height was about $5 \mathrm{~cm}$. The experimental units arranged in a randomized complete block in split-split-plot design with three replicates. The main plot, sub-plot and sub-sub plot were occupied by the factors cutting treatments,cultivars and seeding rates, respectively. The sub-sub plot included four seeding rates, sloid barley $100 \%$ barley $(50 \mathrm{~kg}$ of seeds $\left.\mathrm{fed}^{-1}\right), 75 \%$ barley $\left(37.5 \mathrm{~kg}\right.$ seeds fed ${ }^{-1}$ ) $+25 \%$ berseem $\left(6.25 \mathrm{Kg}\right.$ seeds $\left.\mathrm{fed}^{-1}\right), 50 \%$ barley $\left(25 \mathrm{~kg}\right.$ seeds fed $\left.{ }^{-1}\right)+50 \%$ berseem $(12.5$ $\mathrm{kg}$ seeds $\left.\mathrm{fed}^{-1}\right)$ and $25 \%$ barley $(12.5 \mathrm{~kg}$ seeds $\left.\mathrm{fed}^{-1}\right)+75 \%$ berseem $\left(18.75 \mathrm{~kg}\right.$ seeds $\left.\mathrm{fed}^{-1}\right)$. Statistical analysis was conducted according to the procedure outlined by (Snedecor and Cochran 1980) using MSTAT-C computer program ver.4 (1986). Four early maturing, six rows barley cultivars Giza 133, Giza 134 (hulled barley) Giza 136, Giza 135 (hull-less barley) and Helaly (berseem clover) were planted under 4 seedling rates and two cutting treatments (without cutting and one cut after 45 days from planting. Yield and yield components, i.e., the number of spikes $\mathrm{m}^{2}, 1000-\mathrm{kernel}$ weight $(\mathrm{g})$, the number of kernels/spike, spike kernel weight $(\mathrm{g})$, straw yield $\left(\mathrm{t} \mathrm{fed}^{-1}\right)$, and grain yield $\left(\mathrm{t} \mathrm{fed} \mathrm{d}^{-1}\right)$. Once harvested, the barley crop was evaluated for grain yield, grain yield components, protein content (Kjeldahl method; $\mathrm{N} \mathrm{X} \mathrm{6.25),} \mathrm{fiber} \mathrm{and} \mathrm{ash} \mathrm{percentage.} \mathrm{Chemical}$ analysis followed the conventional methods outlined by the Association of Official Chemists (A. O. A. C., 1990). Seed samples were analyzed in the Seed Technology Research Dept., Field Crops Research Institute ARC, Giza. Egypt.

\section{RESULTS AND DISCUSSION \\ 3.1. Yield and yield components \\ 3.1.1. Number of spikes $\mathbf{m}^{-2}$}

Significant differences for the number of spikes $\mathrm{m}^{-2}$ were observed between all treatments, except for cut $\mathrm{x}$ cultivar and intercropping $\mathrm{x}$ cut in both two seasons. Giza 136 had the highest number of spikes $\mathrm{m}^{-2}$ of solid barley at no cut and one cut (688.91 and 456.30), respectively Table (2). Number of spikes $\mathrm{m}^{-2}$ of solid barley cultivar Giza 136 at no cut and one cut exceeded that of cultivars Giza 133, Giza 134 and Giza 135 by $18.37,15.29$ and $6.53 \%$ at no cutting, $17.60,11.88$ and $16.66 \%$ at one cut, respectively. Number of spikes $\mathrm{m}^{2}$ of Giza 136 at no cut exceeded that one cut $19.66 \%$. The highest number of spikes $\mathrm{m}^{-2}$ was given in intercropping $75 \%$ barley $C V$ Giza 136 with 25 $\%$ berseem at the first season exceeded that of one cut by $26.89 \%$. In the second seasons Giza 136 had the highest number of spikes $\mathrm{m}^{-2}$ of solid barley at seeding rate of at no cut (675.31) and one cut (571.33) Table (2). The number of spikes $\mathrm{m}^{-2}$ of solid barley cultivar Giza 136 at no cut and one cut exceeded that of cultivars Giza 133, Giza 134 and Giza 135 by $18.05,12.57$ and $2.69 \%$ at no cut, $17.65,15.21$ and $12.56 \%$ at one cut, respectively. The highest intercropping $75 \%$ barley $c v$ Giza 136 with $25 \%$ berseem $c v$ Helaly in both no and one cut exceeded that of 
Table(1): Soil physical and chemical analysis of the experimental site at Ismailia in 2012-2013 and 20132014 seasons.

\begin{tabular}{|c|c|c|c|c|c|c|c|c|c|c|}
\hline \multirow[t]{2}{*}{ Season } & \multicolumn{3}{|c|}{ Available (ppm) } & \multirow[t]{2}{*}{$\mathbf{P h}$} & \multirow{2}{*}{$\begin{array}{c}\text { Ec,mm } \\
\text { b/cm }\end{array}$} & \multirow[t]{2}{*}{$\mathrm{CaCo}_{3}$} & \multirow[t]{2}{*}{ Clay\% } & \multirow[t]{2}{*}{ Site\% } & \multirow[t]{2}{*}{ Fine \% } & \multirow{2}{*}{$\begin{array}{c}\text { Soil } \\
\text { texture* }\end{array}$} \\
\hline & $\overline{\mathbf{N}}$ & $\mathbf{P}$ & $\mathbf{K}$ & & & & & & & \\
\hline 2012/ & 19 & 8.2 & 70.20 & 7.4 & 0.06 & 21.0 & 5.08 & 1.30 & 93.4 & Sandy \\
\hline $2013 / 2014$ & 1.91 & 8.4 & 71.0 & 7.7 & 0.06 & 20.8 & 5.10 & 1.28 & 93.5 & Soil \\
\hline
\end{tabular}

*Textural classes according to the triangular diagram.

C. F. Soil and Water Research Institute. A R.C.. Egvbt.

Table( 2): Means of the number of spike $/ \mathrm{m}^{2}$ and 1000 -kernels weight $(\mathrm{g})$ of barley cultivars as affected by cutting treatments and seeding rates in 2012/2013 and 2013/2014 seasons.

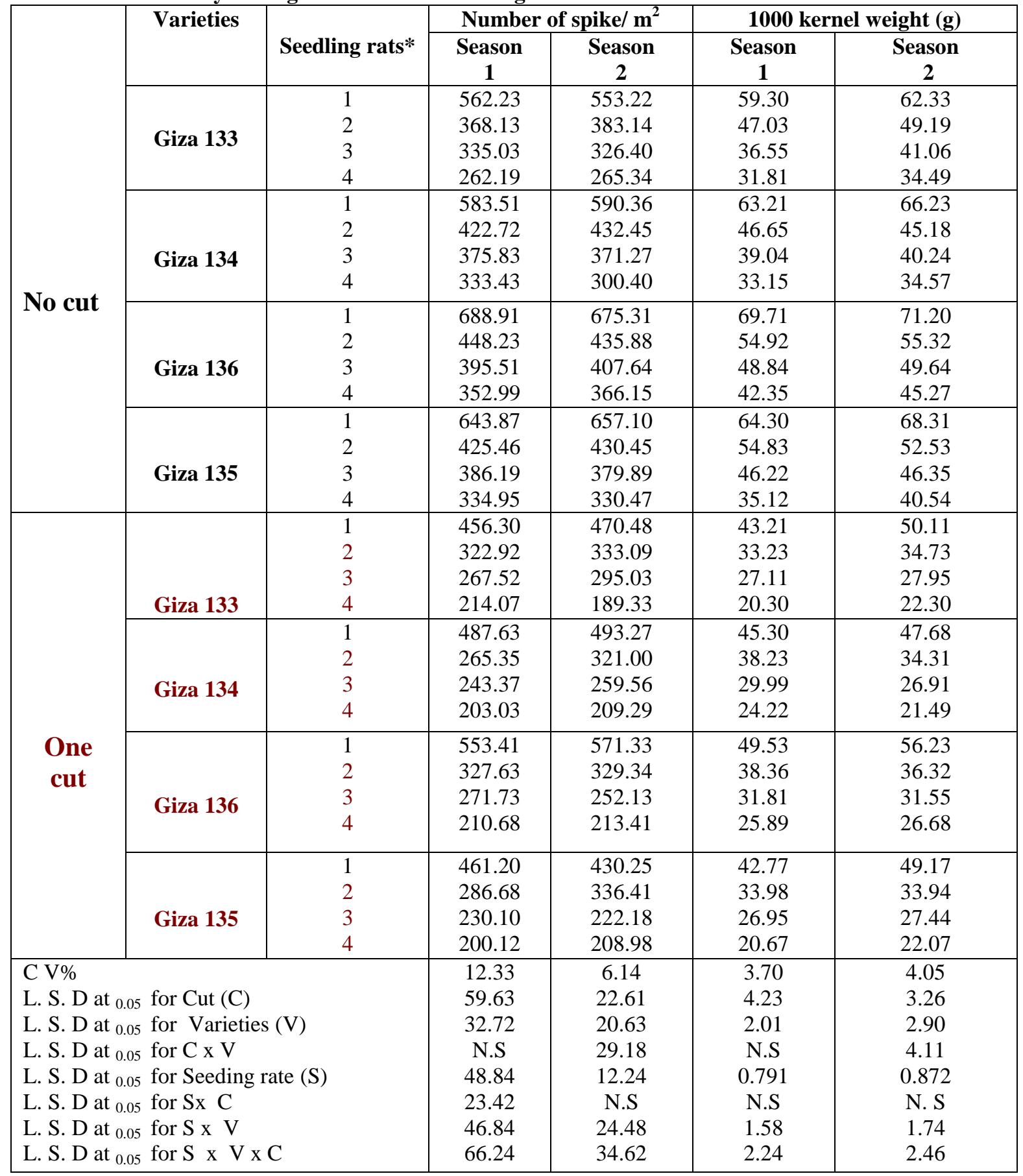

$1-100 \%$ barley $(50 \mathrm{~kg} / \mathrm{fed}) . \quad 2-* 75 \%$ barley $-25 \%$ berseem $(37.5$ barley +6.25 berseem $\mathrm{kg} / \mathrm{fed})$ $3-* 50 \%$ barley-50\% berseem ( 25 barley +12.5 berseem $\mathrm{kg} / \mathrm{fed}$ )

$4-* 25 \%$ barley-75\% berseem $(12.5$ barley +18.75 berseem $\mathrm{kg} / \mathrm{fed}$. 
one cut $24.44 \%$ (Table 2) at the second season.

\subsubsection{0-kernel weight}

The data for 1000-kernel weight in Table

(2) shows significant differences among, cutting,

cultivars, intercropping and their interactions except for cut $\mathrm{x}$ cultivar and intercropping $\mathrm{x}$ cut in both seasons. Giza 136 had the highest 1000 -kernel weight of $69.71 \mathrm{~g}^{-1}$ solid barley at no cut and one cut $\left(49.53 \mathrm{~g}^{-1}\right)$ Table (2). 1000-kernel weight of solid barley cultivar Giza 136 at no cut and one cut exceeded that of cultivars Giza 133, Giza 134 and Giza 135 by $14.93,9.32$ and $7.76 \%$ at no cut, 12.76, 8.54 and $13.64 \%$ at one cut, respectively. 1000-kernel weight of Giza 136 at no cut exceeded that in one cut by $23.69 \%$. The highest 1000-kernel weight was found in intercropping $75 \%$ barley c v Giza 136 with 25 $\%$ berseem $c v$ in at no and one cut exceeded that of one cut $24.55 \%$ at the first season. At the second season Giza136 had the highest number of 1000-kernel weight of solid barley at no cut $\left(675.31 \mathrm{~g}^{-1}\right)$ and one cut $\left(571.33 \mathrm{~g}^{-1}\right)$ Table (2). 1000-kernel weight of solid barley cultivar Giza 136 at no cutting and one cut exceeded that of cultivars Giza 133, Giza 134 and Giza 135 by $12.45,6.98$ and $4.06 \%$ at no cutting, 12.21, 15.20 and $12.56 \%$ at one cut, respectively. The highest 1000-kernel weight was found in intercropping 75\% barley $c v$ Giza 136 with $25 \%$ berseem in both no and one cut exceeded that of one cut $34.71 \%$ at the second season The results of 1000-kernel weight are in harmony with those obtained by Sara et al. (2014).

\subsubsection{Number of kernels/spike}

Results in Table 3 shows that, the number of kernels/spike was highly significantly affected by cut, cultivars, seeding rate and their interactions in both seasons. Data in Table (3) indicate that, the number of kernels/spike of (68.54) solid barley cultivar barley Giza 136 gave the highest value at no cut and one cut (65.84) in the first season. The number of kernels/spike of solid barley cultivar Giza 136 at no cut and one cut exceeded that of cultivars Giza 133, Giza 134 and Giza 135 by $5.41,1.55$ and $2.07 \%$ at no cut, $8.44,6.80$ and $2.28 \%$ at one cut, respectively. The number of kernels/spike of Giza 136 at no cut exceeded that of one cut by $3.93 \%$. The highest number of kernels/spike was found in intercropping of no cut and one cut were $75 \%$ barley Giza $136+$ $25 \%$ cultivar berseem, in the first season $(66.15$ and 62.49), respectively (Table 3). The number of kernels/spike of intercropping barley $75 \%$ barley $c v$ Giza 136 with $25 \%$ berseem $c v$ at no cut exceeded that of one cut $5.85 \%$ in the first season. In the second season data in Table (3) indicate that, the number of kernels/spike of solid barley $50 \mathrm{~kg} / \mathrm{fed}^{-1}$ cultivar barley Giza 136 gave the highest value at no cut (68.91) and one cut (64.95) in the second season. The number of kernels/spike of solid barley cultivar Giza 136 at no cut and one cut exceeded that of cultivars Giza 133, Giza 134 and Giza 135 by 3.60, 3.63 and $3.98 \%$ at no cut, $6.54,6.98$ and $4.34 \%$ at one cut, respectively. The number of kernels/spike of Giza 136 at no cutting exceeded that one cut by $5.75 \%$. The highest number of kernels/spike was given in intercropping of no cut and one cut barley Giza $13675 \%+25 \%$ cultivar berseem in the second season $(67.22$ and 62.76, respectively) Table (3). The number of kernels/spike of intercropping barley $c v$ Giza $13675 \%$ with $25 \%$ berseem $c v$ at no cut exceeded that of one cut $6.63 \%$ in the second season. These results are in harmony with those obtained by Martiniello (1999).

\section{1. 4. Spike kernels weight}

The data in Table (3) shows, for spike kernels weight of the first and second seasons that there were highly significant effects for cutting, cultivars, seeding rate, and their interactions on spike kernels weight in both season. The data in Table (3) shows that, spike kernels weight of solid barley cultivar barley Giza 134 gave the highest value at no cut (2.93 $\mathrm{g})$ and one cut $(2.10 \mathrm{~g})$ in the first season. Spike kernels weight of solid barley cultivar Giza 134 at no cut and one cut exceeded that of cultivars Giza 133, Giza 136 and Giza 135 by 37.20, 19.13 and $31.75 \%$ at no cut, 22.85, 7.14 and $8.33 \%$ at one cut, respectively. Spike kernels weight of Giza 134 at no cut exceeded that one cut by $28.32 \%$. The highest spike kernels weight was given in intercropping of no cut and one cut of barley Giza $134(75 \%)+$ berseem $(25 \%)$ in the first season (1.92 and $1.88 \mathrm{~g}$ ), respectively, as in (Table 3). Spike kernels weight of intercropping barley $c v$ Giza $13475 \%$ with 25 $\%$ berseem, showed that, spike kernels weight of solid barley cultivar barley Giza 134 gave the highest value at no cut $(2.96 \mathrm{~g})$ and one cut $(2.00$ $\mathrm{g}$ ) in the second season. Spike kernels weight of solid barley cultivar Giza 134 at no cutting and one cut exceeded that of cultivars Giza 133, Giza 136 and Giza 135 by 32.47, 9.45 and $29.73 \%$ at no cut, $1.05,1.00$ and $8.50 \%$ at one cut, respectively. Spike kernels weight of Giza 134 at no cut exceeded that one cut $28.32 \%$. The 
Table( 3): Means of number of the kernels / spike and spike kernel weight (g) of barley cultivars as affected by cutting treatments and seeding rates in 2012/2013 and 2013/2014 seasons.

\begin{tabular}{|c|c|c|c|c|c|c|}
\hline & Varieties & & Number & nels / spike & Spike k & ight (g) \\
\hline & & Seeding rate* & $\begin{array}{c}\text { Season } \\
1 \\
\end{array}$ & $\begin{array}{c}\text { Season } \\
2\end{array}$ & $\begin{array}{c}\text { Season } \\
1 \\
\end{array}$ & $\begin{array}{c}\text { Season } \\
2\end{array}$ \\
\hline & & 1 & 64.83 & 66.43 & 1.84 & 1.98 \\
\hline & & 2 & 63.04 & 62.33 & 1.62 & 1.60 \\
\hline & Giza 133 & 3 & 61.71 & 60.44 & 1.49 & 1.7 \\
\hline & & 4 & 59.60 & 57.33 & 1.34 & 1.86 \\
\hline & & 1 & 67.48 & 66.41 & 2.93 & 2.96 \\
\hline & & 2 & 64.81 & 64.63 & 1.92 & 1.99 \\
\hline No cut & Giza 134 & 3 & 63.31 & 56.46 & 1.89 & 1.82 \\
\hline & & 4 & 60.31 & 52.44 & 1.69 & 1.73 \\
\hline & & 1 & 68.54 & 68.91 & 2.37 & 2.68 \\
\hline & & 2 & 66.15 & 67.22 & 1.83 & 1.97 \\
\hline & Giza 136 & 3 & 64.54 & 65.02 & 1.76 & 1.68 \\
\hline & & 4 & 61.89 & 62.55 & 1.65 & 1.49 \\
\hline & & 1 & 67.12 & 66.27 & 2.00 & 2.08 \\
\hline & & 2 & 65.18 & 64.33 & 1.77 & 1.78 \\
\hline & Giza 135 & 3 & 62.47 & 60.12 & 1.68 & 1.76 \\
\hline & & 4 & 61.18 & 60.23 & 1.44 & 1.40 \\
\hline & & 1 & 60.28 & 60.70 & 1.62 & 1.98 \\
\hline & & 2 & 57.63 & 57.31 & 1.52 & 1.60 \\
\hline & Giza 133 & 3 & 46.47 & 51.22 & 1.42 & 1.7 \\
\hline & & 4 & 43.48 & 46.39 & 1.35 & 1.86 \\
\hline & & 1 & 65.84 & 64.95 & 1.95 & 1.98 \\
\hline & & 2 & 62.49 & 62.76 & 1.78 & 1.73 \\
\hline One cut & Giza 136 & 3 & 56.96 & 58.23 & 1.50 & 1.49 \\
\hline & & 4 & 54.39 & 51.30 & 1.46 & 1.41 \\
\hline & & 1 & 64.34 & 62.13 & 1.80 & 1.83 \\
\hline & & 2 & 59.90 & 60.11 & 1.63 & 1.75 \\
\hline & Giza 135 & 3 & 58.15 & 58.71 & 1.52 & 1.78 \\
\hline & & 4 & 56.30 & 57.33 & 1.42 & 1.76 \\
\hline C V\% & & & 2.11 & 1.24 & 2.38 & 3.15 \\
\hline L. S. D at & for Cut (C) & & 5.33 & 4.52 & 2.38 & 3.15 \\
\hline L. S. D at & for Varieti & $(\mathrm{V})$ & 3.54 & 7.63 & 1.14 & 1.11 \\
\hline L. S. D at & for $\mathrm{C} x \mathrm{~V}$ & & 5.31 & 6.10 & 4.88 & 5.10 \\
\hline L. S. D at & for Seeding & ate $(\mathrm{S})$ & 3.10 & 4.11 & 7.10 & 7.33 \\
\hline L. S. D at & for $S \times C$ & & 6.22 & 5.87 & 4.66 & 5.40 \\
\hline L. S. D at & for $S \times V$ & & 5.40 & 4.22 & 7.20 & 8.11 \\
\hline L. S. D at & for $S \times V$ & & 7.12 & 6.14 & 5.66 & 6.66 \\
\hline
\end{tabular}

$1-100 \%$ barley $(50 \mathrm{~kg} / \mathrm{fed}) . \quad 2-* 75 \%$ barley $-25 \%$ berseem $(37.5$ barley +6.25 berseem $\mathrm{kg} / \mathrm{fed})$

$3-* 50 \%$ barley-50\% berseem ( 25 barley +12.5 berseem $\mathrm{kg} / \mathrm{fed}$ )

4- $* 25 \%$ barley-75\% berseem ( 12.5 barley +18.75 berseem $\mathrm{kg} / \mathrm{fed}$

highest spike kernels weight was given in intercropping of no cut and one cut barley Giza $134(75 \%)+25 \%$ berseem in the second season (1.99 and $1.90 \mathrm{~g}$ ), respectively (Table 3). Spike kernels weight in intercropping barley $c v$ Giza $134(75 \%)$ with $25 \%$ berseem at no cut exceeded that of one cut $4.53 \%$ in the secondseason. These results are in harmony with those obtained by Sara et al. (2014).

\section{1. 5. Straw yield}

Data in Table (4) shows highly significant effect for cutting, cultivars, seeding rate, and their interactions in both seasons. The data in
Table (4) shows that, straw yield of solid barley $50 \mathrm{~kg} / \mathrm{fed}^{-1}$ cultivar barley Giza 133 gave the highest value at no cut $\left(5.20 \mathrm{t} \mathrm{fed}^{-1}\right)$ and one cut $\left(2.85 \mathrm{t} \mathrm{fed}^{-1}\right)$ in the first season. For straw yield of solid barley cultivar Giza 133 at no cutting and one cut exceeded that of cultivars Giza 134, Giza 136 and Giza 135 by $20.96,30.77$ and $25 \%$ at no cutting, $11.22,6.67$ and $12.98 \%$ at one cut, respectively. Straw yield of Giza 133 at no cutting exceeded that of one cut $51.53 \%$. The highest straw yield was given by intercropping of no cut and one cut barley Giza $133(75 \%)+$ $25 \%$ berseem in the first season $(3.85$ and $2.62 \mathrm{t}$ 
Table (4): Means of straw yield $\left(\mathrm{t} \mathrm{fad}^{-1}\right)$ and grain yield $\left(\mathrm{t} \mathrm{fad}^{-1}\right)$ of barley cultivars as affected by cutting treatments and seeding rates in 2012/2013 and 2013/2014 seasons.

\begin{tabular}{|c|c|c|c|c|c|c|}
\hline & Varieties & & Straw & $\left(\mathrm{t} \mathrm{fad}^{-1}\right)$ & Grain & $\left(t\right.$ fed $\left.^{-1}\right)$ \\
\hline & & Seeding rate* & $\begin{array}{c}\text { Season } \\
1 \\
\end{array}$ & $\begin{array}{c}\text { Season } \\
2 \\
\end{array}$ & $\begin{array}{c}\text { Season } \\
1 \\
\end{array}$ & $\begin{array}{c}\text { Season } \\
2 \\
\end{array}$ \\
\hline & & 1 & 4.20 & 5.88 & 1.96 & 1.51 \\
\hline & & 2 & 3.45 & 3.24 & 1.88 & 1.90 \\
\hline & Giza 133 & 3 & 2.62 & 2.66 & 1.79 & 1.71 \\
\hline & & 4 & 2.16 & 2.22 & 1.47 & 1.47 \\
\hline & & 1 & 4.11 & 4.96 & 2.07 & 2.08 \\
\hline & & 2 & 2.48 & 2.58 & 1.85 & 1.91 \\
\hline No cut & Giza 134 & 3 & 2.30 & 2.48 & 1.75 & 1.70 \\
\hline & & 4 & 1.92 & 2.10 & 1.61 & 1.56 \\
\hline & & 1 & 3.60 & 4.55 & 2.36 & 2.39 \\
\hline & & 2 & 3.26 & 3.25 & 2.02 & 1.99 \\
\hline & Giza 136 & 3 & 3.18 & 3.21 & 1.87 & 1.82 \\
\hline & & 4 & 2.67 & 2.79 & 1.64 & 1.65 \\
\hline & & 1 & 3.90 & 3.82 & 2.23 & 2.24 \\
\hline & & 2 & 3.47 & 3.54 & 1.81 & 1.90 \\
\hline & Giza 135 & 3 & 2.66 & 3.07 & 1.63 & 1.59 \\
\hline & Giva 10\% & 4 & 2.22 & 2.36 & 1.46 & 1.49 \\
\hline & & 1 & 2.85 & 3.09 & 1.51 & 1.34 \\
\hline & & 2 & 2.32 & 2.67 & 1.51 & 1.48 \\
\hline & Giza 133 & 3 & 1.71 & 2.05 & 1.37 & 1.32 \\
\hline & & 4 & 1.33 & 1.88 & 0.98 & 1.01 \\
\hline & & 1 & 2.53 & 2.67 & 1.71 & 1.63 \\
\hline & & 2 & 2.42 & 2.69 & 1.56 & 1.62 \\
\hline & Giza 134 & 3 & 1.94 & 2.17 & 1.32 & 1.24 \\
\hline & 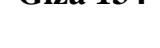 & 4 & 1.28 & 1.74 & 1.12 & 1.17 \\
\hline One cat & & 1 & 2.66 & 2.77 & 1.83 & 1.79 \\
\hline & & 2 & 1.97 & 1.87 & 1.76 & 1.63 \\
\hline & Giza 136 & 3 & 2.08 & 2.41 & 1.53 & 1.47 \\
\hline & & 4 & 1.73 & 2.00 & 1.25 & 1.26 \\
\hline & & 1 & 1.86 & 2.45 & 1.72 & 1.63 \\
\hline & & 2 & 2.48 & 2.58 & 1.67 & 1.56 \\
\hline & Giza 135 & 3 & 2.04 & 2.08 & 1.41 & 1.39 \\
\hline & & 4 & 1.43 & 1.74 & 1.23 & 1.23 \\
\hline $\mathrm{C} \mathrm{V} \%$ & & & 6.51 & 5.15 & 4.90 & 3.86 \\
\hline L. S. D at ${ }_{0.0}$ & Cut (C) & & 0.064 & 0.084 & 0.882 & 0.924 \\
\hline L. S. D at 0.0 & Varieties ( & & 0.269 & 0.133 & 0.785 & 0.506 \\
\hline L. S. D at 0.0 & $\mathrm{C} \times \mathrm{V}$ & & N.S & 0.189 & N.S & 0.717 \\
\hline L. S. D at ${ }_{0.0}$ & Seeding rat & & 0.091 & 0.108 & 0.318 & 0.278 \\
\hline L. S. D at 0.0 & $\mathrm{~S} \times \mathrm{C}$ & & 0.129 & 0.153 & 0.450 & 0.394 \\
\hline L. S. D at 0.0 & $\mathrm{Sx} \quad \mathrm{V}$ & & 0.182 & 0.216 & 0.637 & 0.557 \\
\hline L. S. D at ${ }_{0.0}$ & $\mathrm{~S} \times \mathrm{V} \times \mathrm{C}$ & & 0.258 & 0.306 & 0.900 & 0.964 \\
\hline
\end{tabular}

fed $^{-1}$ ), respectively (Table 4). Straw yield of intercropping barley $C V$ Giza 133 (75\%) with $25 \%$ berseem $c v$ at no cut exceeded that of one cut $31.95 \%$ in the first season. The data in Table (4) showed that in the second season, straw yield of solid barley cultivar barley Giza 133 gave the highest value at no cut $\left(5.88 \mathrm{t} \mathrm{fed}^{-1}\right)$ and one cut $\left(3.09 \mathrm{t} \mathrm{fed}^{-1}\right)$ in the second season. Straw yield of solid barley cultivar Giza 133 at no cut and one cut exceeded that of cultivars Giza 134, Giza 136 and Giza 135 by $15.64,22.62$ and $35.03 \%$ at no cutting, $13.60,10.36$ and $20.71 \%$ at one cut, respectively. The highest straw yield was given by intercropping of no cut and one cut were 


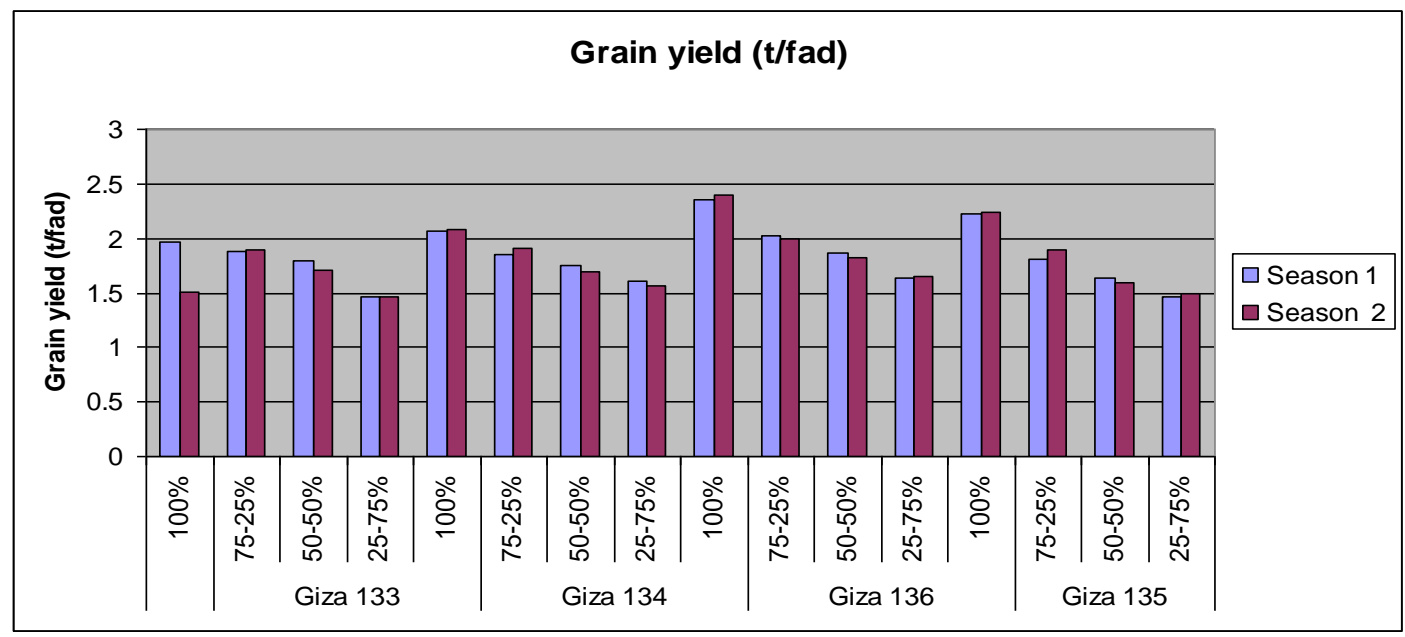

Fig. (1): Means of grain yield $\left(\mathrm{t} \mathrm{fad}^{-1}\right)$ of barley cultivars as affected by no cutting treatments seeding rats in 2012/2013 and 2013/2014 seasons.

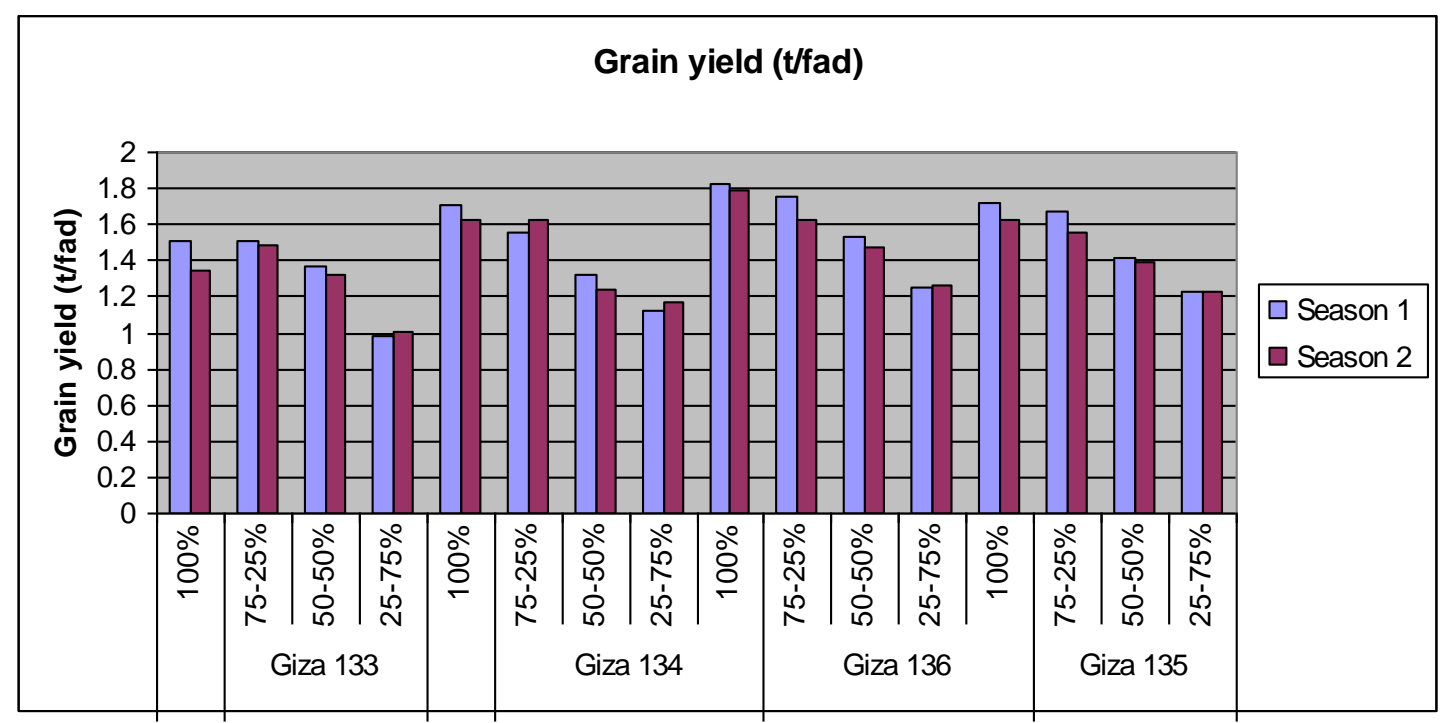

Fig. (2): Means of grain yield $\left(\mathrm{t} \mathrm{fad}^{-1}\right)$ of barley cultivars as affected by one cutting treatments seeding rats in 2012/2013 and 2013/2014 seasons.

barley Giza 133(75\%) $+25 \%$ berseem in the second season (66.15 and $\left.67.22 \mathrm{t} \mathrm{fed}^{-1}\right)$, respectively (Table 4). Straw yield of intercropping barley $c v$ Giza $133(75 \%)$ with 25 $\%$ berseem at no cut exceeded that of one cut $32.23 \%$ in the second season.

\section{1. 6. Grain yield}

The data in Table (4) shows highly significant effects for cutting, cultivars, seeding rate, and their interactions in both seasons. The data in Table (4) shows that, grain yield of solid barley Giza $136(100 \%)$ gave the highest value at no cut $\left(2.36 \mathrm{~T} \mathrm{fed}^{-1}\right)$ and one cut $\left(1.83 \mathrm{~T} \mathrm{fed}^{-1}\right)$ in the first season. For grain yield of solid barley cultivar Giza 136 at no cutting and one cut exceeded that of cultivars Giza 133, Giza 134 and Giza 135 by $16.80,12.27$ and $5.50 \%$ at no cutting, 17.14, 6.56 and $5.98 \%$ at one cut, respectively. Grain yield of Giza 136 at no cutting exceeded that of one cut $22.45 \%$. The highest grain yield was given by intercropping of no cut and one cut barley Giza $136(75 \%)+25 \%$ cultivar berseem $\mathrm{C} \mathrm{V}$ in the first season 2.02 and $1.76 \mathrm{~T} \mathrm{fed}^{-1}$ ), respectively (Table 4). Grain yield of intercropping barley $c v$ Giza 136 (75\%) with $25 \%$ berseem $c v$ at no cut exceeded that of one cut $12.50 \%$ in the first season. Data in table (4) shows that, grain yield of solid barley $(100 \%$ barley) cultivar barley Giza 136 gave the highest value at no cut $\left(2.39 \mathrm{~T} \mathrm{fed}^{-1}\right)$ and one cut $(1.79 \mathrm{~T}$ $\left.\mathrm{fed}^{-1}\right)$ in the second season. Grain yield of solid barley cultivar Giza 136 at no cut and one cut exceeded that of cultivars Giza 133, Giza 134 and Giza 135 by $37.09,13.13$ and $6.62 \%$ at no 
cutting, $24.73,8.74$ and $8.67 \%$ at one cut, respectively. The highest grain yield was by intercropping of no cut and one cut were $75 \%$ barley Giza $136+25 \%$ cultivar berseem in the second season (1.99 and $\left.1.63 \mathrm{~T} \quad \mathrm{fed}^{-1}\right)$, respectively (Table 4). Grain yield was given of intercropping barley cv Giza 136 (75\%) with 25 $\%$ berseem $c v$ at no cut exceeded that of one cut $18.25 \%$ in the second season. Ross et al. (2004 a and b) reported that at intercropping of barley and vetch maximum grain yield was belong to sole barley culture. These results are in harmony with those obtained by Holland and Brummer (1999) and Sara et al. (2014).

\section{2. Chemical composition of barley seeds}

The data in Table (5) shows a significant effect of cutting, cultivars, seeding rate, and their interactions on protein, ash and fiber\% in barley grains in 2012/2013 and 2013/2014 seasons.

\subsubsection{Crude protein $\%$}

Protein content in grains averaged across cultivar was recorded for the cultivars Giza 136 at both seasons. Whereas, an increase of this value was observed at seeding rate of solid barley(100\% barley) cultivar barley Giza 136 at no and one cut 12.85 and $11.54 \%$ in the first season 12.79 and $11.40 \%$ in the second season, respectively in Table (5), Fig (3 and 4). In both seasons, the highest protein \% were given by intercropping $(75 \%$ cv. 136 barley $+25 \%$ berseem) at no and one cut in the first and second seasons which recorded 12.66 and $11.19 \% 12.30$ and $11.15 \%$, in the first and second seasons respectively (Table 5, Fig 3 and 4). McAndrews, et al.,(2004) reported that berseem fixed about $188 \mathrm{~kg} \mathrm{~N} \mathrm{ha}^{-1}$ when measured with $\mathrm{N}^{15}$. In addition, legumes have greater leaves to stem ratio which is a primary sites of photosynthesis and enzymes activity.

\section{2. 2. Crude ash \%}

High crude ash content in the grains was recorded for cultivar Giza 134 at the both seasons. Whereas an increase of this value was observed at seeding rate of (100\% barley) solid barley at no and one cut 17.32 and $15.79 \%$ in the first season 17.56 and $14.29 \%$ in the second season, respectively in Table (5). In the first and second season the highest ash \% was given by intercropping $(75 \%$ cv. 134 barley $+25 \%$ berseem) at no and one cut in the first and second seasons, which recorded 17.00 and $15.63 \%$ in the first season, 17.11 and $14.01 \%$ in the second one, respectively (Table 5). The decline in crude fiber of barley may be explained by thinned stem and /or better leaf / stem ratio in successive cutting. These results can be supported by those of crude protein in the same table. These results are in agreement with those obtained by Helmy et al., (2011).

\section{2. 3. Fiber $\%$}

Barley cultivars Giza 136 in (100\%) solids gave the highest percentages of fiber\% among cultivars at no and one cut 39.93 and $26.36 \%$ in the first season 30.11 and $26.54 \%$ by the second season, respectively, in Table (5). In the first and second seasons the highest fiber\% was given in

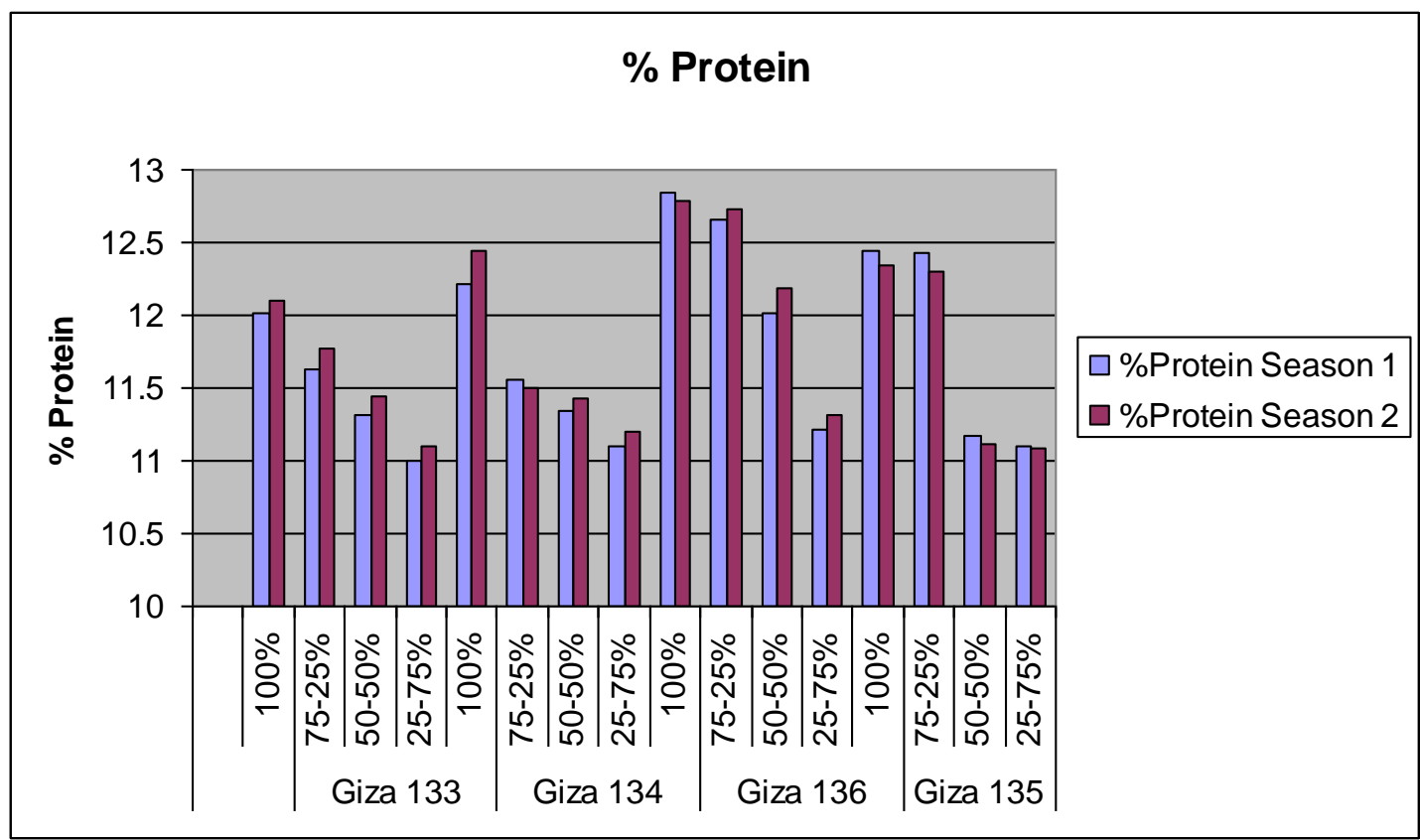

Fig. (3): Mean of protein (\%) of seeds of barley cultivars as affected by no cutting treatments seeding rats in 2012/2013 and 2013/2014 seasons. 
Table (5): Mean of protein, ash and fiber (\%) of seeds of barley cultivars as affected by cutting treatments and seeding rates in 2012/2013 and 2013/2014 seasons.

\begin{tabular}{|c|c|c|c|c|c|c|c|c|}
\hline \multirow{18}{*}{ No cut } & \multirow[t]{2}{*}{ Varieties } & \multirow{2}{*}{$\begin{array}{c}\text { Seeding } \\
\text { rates* }\end{array}$} & \multicolumn{2}{|c|}{ \% Protein } & \multicolumn{2}{|c|}{$\%$ Ash } & \multicolumn{2}{|c|}{$\%$ Fiber } \\
\hline & & & $\begin{array}{c}\text { Season } \\
1\end{array}$ & $\begin{array}{c}\text { Season } \\
2\end{array}$ & $\begin{array}{c}\text { Season } \\
1\end{array}$ & $\begin{array}{c}\text { Season } \\
2\end{array}$ & $\begin{array}{c}\text { Season } \\
1\end{array}$ & $\begin{array}{c}\text { Season } \\
2\end{array}$ \\
\hline & \multirow{4}{*}{ Giza 133} & 1 & 12.01 & 12.10 & 17.24 & 17.36 & 30.47 & 31.20 \\
\hline & & 2 & 11.63 & 11.77 & 16.73 & 16.80 & 29.09 & 30.20 \\
\hline & & 3 & 11.32 & 11.45 & 16.53 & 16.20 & 28.47 & 27.71 \\
\hline & & 4 & 11.00 & 11.10 & 15.98 & 15.98 & 26.84 & 27.66 \\
\hline & \multirow{4}{*}{ Giza 134} & 1 & 12.21 & 12.44 & 17.32 & 17.56 & 29.86 & 31.55 \\
\hline & & 2 & 11.55 & 11.50 & 17.00 & 17.11 & 29.63 & 31.21 \\
\hline & & 3 & 11.35 & 11.43 & 16.46 & 17.03 & 28.84 & 29.95 \\
\hline & & 4 & 11.10 & 11.20 & 16.04 & 16.86 & 26.47 & 28.08 \\
\hline & \multirow{4}{*}{ Giza 136} & 1 & 12.85 & 12.79 & 17.03 & 17.57 & 39.93 & 30.11 \\
\hline & & 2 & 12.66 & 12.73 & 16.48 & 16.54 & 29.36 & 29.96 \\
\hline & & 3 & 12.01 & 12.19 & 15.59 & 16.40 & 28.16 & 28.80 \\
\hline & & 4 & 11.22 & 11.32 & 15.41 & 14.97 & 24.23 & 24.63 \\
\hline & \multirow{4}{*}{ Giza 135} & 1 & 12.45 & 12.35 & 17.17 & 17.09 & 29.05 & 29.78 \\
\hline & & 2 & 12.43 & 12.30 & 16.08 & 16.17 & 28.15 & 28.69 \\
\hline & & 3 & 11.17 & 11.11 & 15.79 & 15.90 & 27.25 & 27.92 \\
\hline & & 4 & 11.10 & 11.08 & 15.50 & 15.67 & 24.11 & 26.73 \\
\hline \multirow{16}{*}{ One cut } & \multirow{4}{*}{ Giza 133} & 1 & 10.44 & 10.66 & 14.64 & 14.95 & 25.36 & 25.71 \\
\hline & & 2 & 10.23 & 10.29 & 14.27 & 14.89 & 25.08 & 25.18 \\
\hline & & 3 & 10.01 & 10.17 & 14.00 & 14.20 & 23.44 & 24.00 \\
\hline & & 4 & 9.88 & 9.70 & 13.11 & 13.09 & 21.09 & 21.15 \\
\hline & \multirow{4}{*}{ Giza 134} & 1 & 10.58 & 10.71 & 15.79 & 14.88 & 24.70 & 24.80 \\
\hline & & 2 & 10.25 & 10.32 & 15.63 & 24.68 & 24.52 & 24.63 \\
\hline & & 3 & 10.10 & 10.11 & 14.46 & 14.30 & 23.12 & 23.40 \\
\hline & & 4 & 9.70 & 9.60 & 13.11 & 14.10 & 22.14 & 22.56 \\
\hline & \multirow{4}{*}{ Giza 136} & 1 & 11.54 & 11.40 & 14.94 & 14.29 & 26.33 & 26.54 \\
\hline & & 2 & 11.19 & 11.15 & 14.74 & 14.01 & 25.12 & 25.47 \\
\hline & & 3 & 11.07 & 10.93 & 14.42 & 13.57 & 24.01 & 24.20 \\
\hline & & 4 & 10.78 & 10.68 & 14.15 & 13.20 & $23 . .11$ & 23.17 \\
\hline & \multirow{4}{*}{ Giza 135} & 1 & 11.40 & 11.02 & 15.75 & 15.81 & 25.07 & 25.43 \\
\hline & & 2 & 11.03 & 10.88 & 15.43 & 15.40 & 24.08 & 24.55 \\
\hline & & 3 & 10.44 & 10.45 & 14.35 & 14.33 & 23.44 & 23.56 \\
\hline & & 4 & 10.06 & 10.00 & 14.18 & 14.16 & 21.09 & 21.16 \\
\hline \multicolumn{3}{|l|}{$\mathrm{C} \mathrm{V} \%$} & 5.21 & 6.30 & 4.10 & 7.11 & 6.20 & 5.30 \\
\hline \multicolumn{3}{|c|}{ L. S. D at ${ }_{0.05}$ for Cut (C) } & 5.72 & 0.339 & 1.07 & 4.57 & 8.001 & 4.361 \\
\hline \multicolumn{3}{|c|}{ L. S. D at ${ }_{0.05}$ for Varieties (V) } & 0.386 & 0.345 & 0.985 & 1.063 & 0.859 & 1.061 \\
\hline \multicolumn{3}{|c|}{ L. S. D at ${ }_{0.05}$ for $\mathrm{C} \mathrm{x} \mathrm{V}$} & 0.44 & 1.02 & 1.392 & 1.14 & 1.22 & 1.502 \\
\hline \multicolumn{3}{|c|}{ L. S. D at 0.05 for seeding rate $(\mathrm{S})$} & 0.162 & 0.112 & 0.252 & 0.245 & 0.951 & 0.589 \\
\hline \multicolumn{3}{|c|}{ L. S. D at ${ }_{0.05}$ for $S \times C$} & 0.229 & 0.336 & 0.357 & 0.534 & 0.837 & 0.834 \\
\hline \multicolumn{3}{|c|}{ L. S. D at ${ }_{0.05}$ for $\mathrm{S} \times \mathrm{V}$} & 0.324 & 0.338 & 0.505 & 0.424 & 1.183 & 0.838 \\
\hline \multicolumn{3}{|c|}{ L. S. D at ${ }_{0.05}$ for $S \times V \times C$} & 0.459 & 0.478 & 0.713 & 0.759 & 1.670 & 1.190 \\
\hline
\end{tabular}

intercropping $75 \%$ barley cv 136 with $25 \%$ berseem in no and one cut in the first and second seasons which recorded 29.36 and $25.12 \%$ in the first season 29.96 and $25.47 \%$ in the second season respectively. These results confirmed the finding of Abdel-Aziz et al. (2007).

\section{CONCLUSIONS}

The results of this study indicated that intercropping barley with berseem clover at the seeding rate of Giza $136 C V$ 37.5-Helally $C V$ 6.25 seeds $\mathrm{kg} / \mathrm{fad}^{-1}(75-25 \%)$ in both no and one cut provided the highest advantage in all characters of this study. Also the data showed that the highest cultivar was Giza 136 (Hull-less barley) for soled barley (100\%) at no and one cut in most characters of this study. 


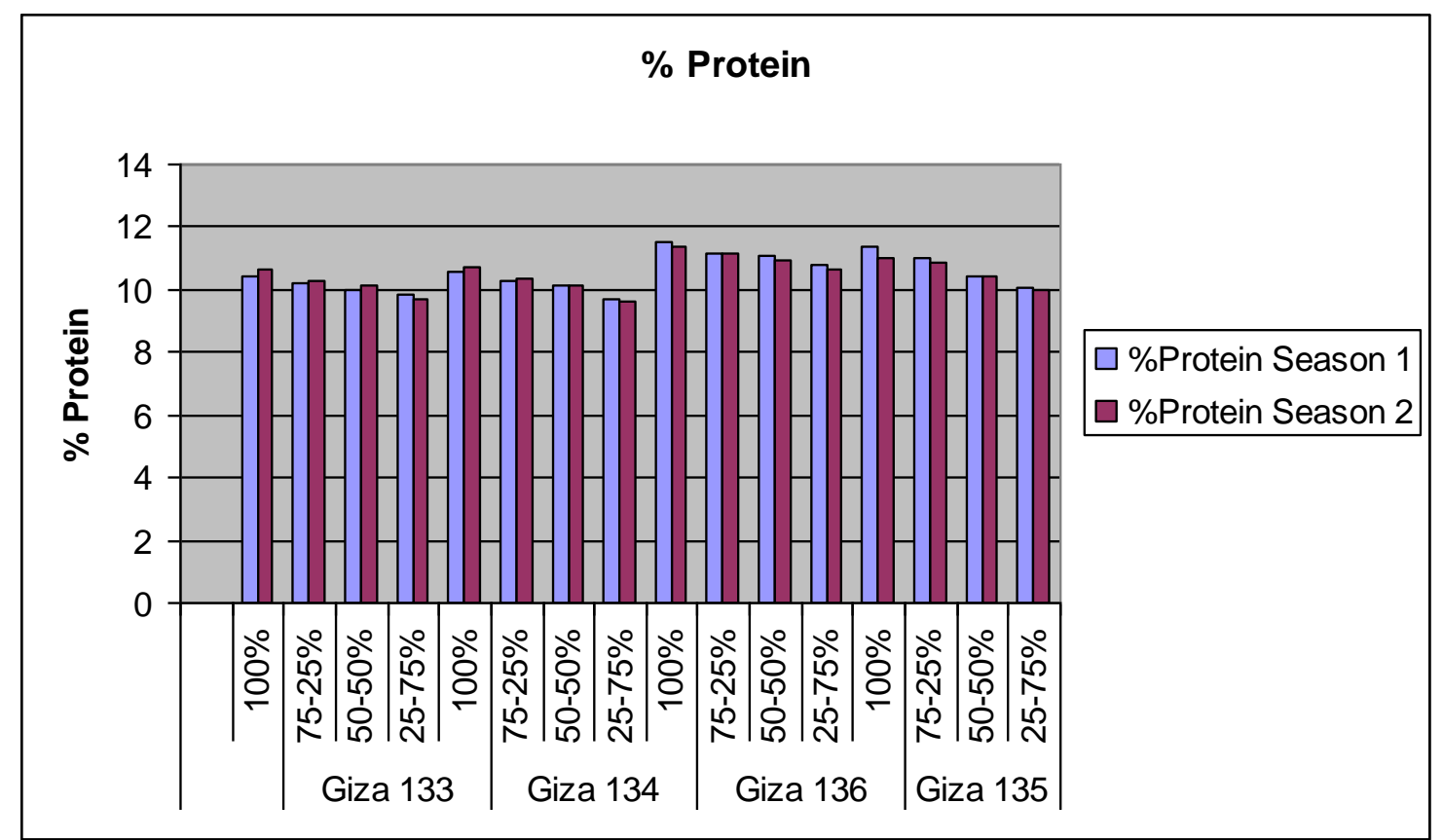

Fig.(4): Mean of protein (\%) of seeds of barley cultivars as affected by one cutting treatments seeding rats in 2012/2013 and 2013/2014 seasons.

\section{REFERENCES}

Abdel-Aziz T. K, El-Shereif A. A. M. M. Azab and N. M. Hamed (2007). Influence of seeding rates and $\mathrm{N}$ fertilizer on forage yield and quality of berseem-ryegrass mixture. J. Agric. Sci.Mansoura Univ., 32 (2): 1583-1600.

Adesogan A. T., Salawa M. B. and Deaville E. (2000). The effect on voluntary feed intake, in vivo digestibility and nitrogen balance in sheep of feeding grass silage or pea-wheat intercrops differing in pea to wheat ratio and maturity. Animal feed Sci. and Tech., 96: 161-173.

Anil L., Park J., Phipps R. H. and Miller F. A. (1998). Temperate intercropping of cereals for forage: A review of the potential for growth and utilization with particular reference to the UK. Grass Forage Sci. 53:301-317.

A. O. A. C. (1990). Official Methods of Analysis. Association of official Analysis chemists. $11^{\text {th }}$ Ed., P. O. Box 540, Washingt, D. C., USA.

Caballero R., Goicoechea E. L. and Hernaiz P. J. (1995). Forage yields and quality of common vetch and oat sown at varying seeding ratios and seeding rates of vetch. Field Crops Res. 41:135-140.

Helmy A., Wafaa M. and Hoda I. M. (2011). Evaluation of fodder yield and its quality of barley and with berseem clover. J. Plant Prod., Mansoura Univ., 2 (7): 851-863.

Holland J. B. and Brummer E. C. (1999). Cultivar effects on oat-berseem clover intercrops. Agron. J., 91:321-329.

Jedel P.E. and Helm J.H. (1995). Agronomic response to seeding rate two-and sixrowed barley cultivars in Central Alberta. Can. J. Plant Sci., 75(2): 315-320.

Lawes D. A. and Jones D. I. H. (1971). Yield, nutritive value and ensiling characteristics of whole-crop spring cereals. J. Agric., Sci., 76:479-485.

Martiniello P. (1999). Effects of irrigation and harvest management on dry matter yield and seed yield of annual clovers grown in solid and in mixtures with graminaceous species in the Mediterranean environment. Grass Forage Sci., 54:52-61.

McAndrews G. M., Franke K., Moore K. and George, R. (2004). Forage yield and nutritive value of oat interseeded with berseem clover and barley. On line Crop Management doi: 10. 1094/CM-20040301-01-RS.

Ofori F. and W. R. Stern. (1987). Cereal-legume intercropping systems. Adv. Agron., 41:41-90.

Osman A. E. and Nersoyan N. (1986). Effect of the proportion of species on the yield and 
quality of forage mixtures, and on the yield of barley in the following year. Exp. Agric., 22:345-351.

Papastylianou I. (2004). Effect of rotation system and $\mathrm{N}$ fertilizer on barley and common vetch grown in various crop combinations and cycle lengths. J. Agric. Sci., 142:41-48.

Robinson R. C. (1969). Annual legume:cereal mixtures for forage and seed. Agron. J., 61:759-761.

Ross M., Donovan J. T. O. and Spaner D. (2004a). Forage potential of intercropping berseem clover with barley, oat or triticale, Agric., Sci. 134:285-291

Ross M.,. King J. R 'Donovan J. T. O and Spaner D. (2004b).Intercropping berseem clover with barley and oat for forage. Agron. J. 96: 1719-1729.

Sara N., Bonjar A. G., Ramroudi M. and Sirousmehr A. (2014). Evaluation of yield and yield components in intercropping of barley with clover. Inte. J. Agron. and Agric. Res. (IJAAR) , 5, (4) P.: 31-39.

Snedecor G. W. and Cochran W.G. (1980). Statistical Methods, $7^{\text {th }}$ Ed. 507 pp. lowa State Univ. Press, Ames lowa. USA.

\footnotetext{
تقييم إنتاجية أربع اصناف جديدة من الثعير عند تحميلها مع البرسيم المصري

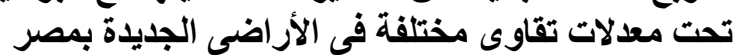

محمد زكريا محمود شندى

قسم بحوث الثعبر ـمعهد المحاصيل الحقلية_مركز البحوث الزر اعيةـ الجيزة ـ مصر

ملخص

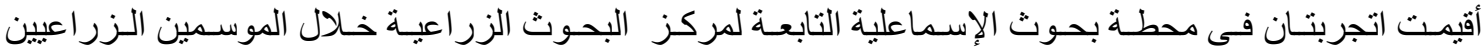

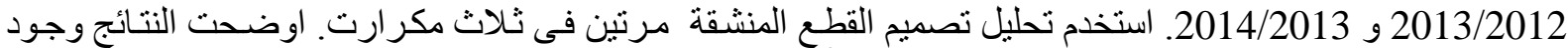

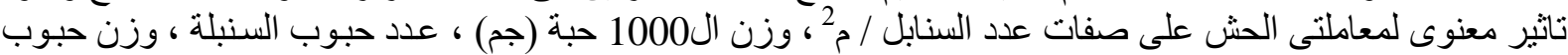

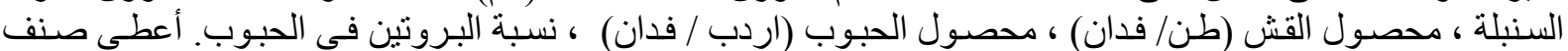

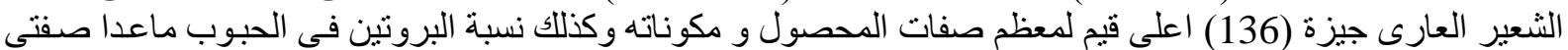

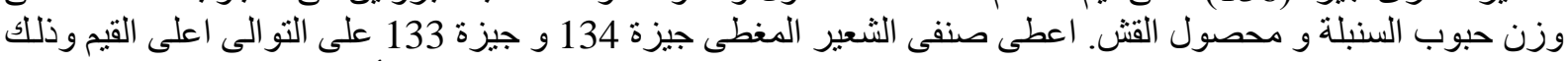

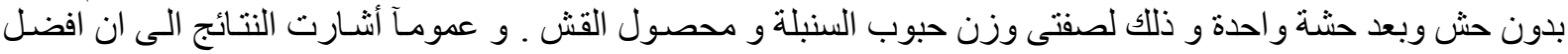

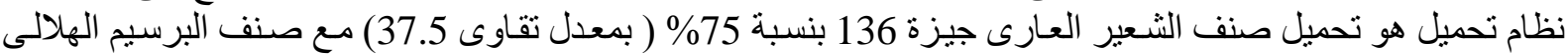

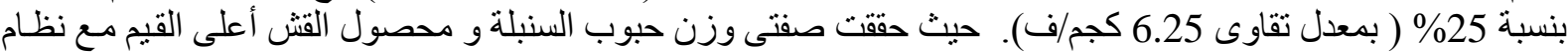
التحميل \%5 \% صنف الثعير العارى جيزة 135 و و صنف جيزة 134 أو جيزة 133 - 25\% مع صنف البرسيم الهلالى

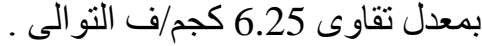

المجلة العلمية لكلية الزراعة - جامعة القاهرة ـ المجلا (66) العدد الأول (يناير2015): 29-39.
} 